\title{
Determination by molecular methods of genetic and epigenetic changes caused by heavy metals released from thermal power plants
}

\author{
Hüseyin Bulut ${ }^{1} \cdot$ Nalan Yıldırım Doğan ${ }^{2}$
}

Received: 26 December 2017 / Accepted: 15 January 2018/Published online: 3 February 2018

(C) The Korean Society for Applied Biological Chemistry 2018

\begin{abstract}
The heavy metals are released into the environment due to the activities such as meeting the increasing demand for energy, industrial activities, and agricultural pesticides. In many studies, the heavy metals have been proven to have genotoxic effects. As a result of burning the lignite coal in thermal power plants, the heavy metals of $\mathrm{Cr}, \mathrm{Fe}, \mathrm{Mn}, \mathrm{Cu}, \mathrm{Pb}, \mathrm{Cd}, \mathrm{Zn}$, and $\mathrm{Ni}$ are spread into the environment within the ashes. In the present study, the gene expression levels were examined on the corn and wheat plants added with 500-m interval around the thermic power plant. For this purpose, the genes from 14-3-3 protein family, expression level of which increases under abiotic stress conditions, were analyzed. For the expression levels of plants, the $2^{-\Delta \Delta C_{\mathrm{t}}}$ values were calculated and then compared to $2^{-\Delta \Delta C_{\mathrm{t}}}$ values of $\beta$-actin gene, that is, the housekeeping gene. The heavy metal content analyses of the samples were carried out using ICP-MS, and it was determined that there were many heavy metals at higher amounts within the structure of samples having low level of gene expression. It has been understood that heavy metal stress causes a difference in gene expression level. The change introduced by heavy metal stress into the gene expression occurs in concrete in the translation products. The level of stress-induced gene expression, which is
\end{abstract}

Hüseyin Bulut

huseyinbulut@erzincan.edu.tr

Nalan Yıldırım Doğan

nyildirim@erzincan.edu.tr

1 Üzümlü Vocational School, Erzincan University, Erzincan, Turkey

2 Department of Biology, Faculty of Science and Arts, Erzincan University, 24000 Erzincan, Turkey caused by heavy metals in the environment surrounding the plant, has been successfully determined by RT-PCR.

Keywords Epigenetic - Gene expression - Genotoxic effect · Heavy metal $\cdot$ ICP-MS $\cdot$ Thermal power plant

\section{Introduction}

In proportion to the increase in world population, the intensity of vehicle traffic, the industrial production, the industrialization, and energy requirement increase [1]. The pollution occurring due to the release of heavy metals as a result of the activities conducted in order to meet the requirements became one of the most important problems in our environment [2].

The heavy metal contamination of the soil arises as a result of the factors such as agricultural pesticides, processing the underground mineral resources for the use, burning the fossil fuels such as coal, waste of batteries, and irrigation by using polluted water sources [3-6].

In previous studies, it was shown that $\mathrm{Cu}, \mathrm{Hg}, \mathrm{Pb}$, and $\mathrm{Cr}$ cause the oxidative stress in organisms and this increases the DNA damage [7-9]. Although zinc has been reported to be the heavy metal species that has the lowest toxic effect, it has also been stated that excessive accumulation of zinc in plant tissues caused cytotoxic and genotoxic effects due to DNA damage [10-12]. Similarly, as a result of the increase in production of free radicals by $\mathrm{Ni}$ and $\mathrm{Cr}$, the point mutations and chain fractures have been reported [13-16]. In previous studies, it was reported that excessive accumulation of copper in plant tissues caused formation of free oxygen radicals and its toxic 
effect for the plants was higher than other nonessential heavy metals $[17,18]$.

The influence of epigenetic modifications happening on the chromatin structure to the expression of genes is being controlled by the basic epigenetic mechanisms such as DNA methylation, histone modifications, and RNA [19]. The cooperation of these three mechanisms leads to inheritable differences in the gene expression. A mistake occurring in either mechanisms leads to epigenetic disorders resulting in excessive increase or suppression of gene expression [20].

The basic nutrients of living beings are the grains. Grain production in our country is equal to half of the products grown. TSI [21] our country acreage of Triticum aestivum L. (Wheat) and Zea mays L. (Corn) products in the last 5 years, according to the size and quantity of the product Fig. 1.

Our purpose in this study is to determine the plantation distance to heavy metal source by using the change in gene expression levels of staple foods wheat and corn cereals as a result of the genotoxic effects of heavy metals.

\section{Materials and methods}

\section{Seed sowing and sampling}

Selected equal-sized wheat and corn seeds were sowed at 20 distinct points so as to $500 \mathrm{~m}$ apart from each other in the same direction around the thermal power plant. As the control group, the seeds were sowed within the same region yet outside the effect of thermal power plant. Following a 40-day vegetation period, the sample plants were collected.
Collected samples were sterilized prior to molecular investigations and heavy metal content analysis.

\section{RNA isolation}

After putting the leaves of wheat and corn samples by liquid nitrogen in dust, RNA isolation was performed by Ribospin Plant 307-150 kit in accordance with the instructions of the manufacturer.

\section{Determination of RNA concentrations}

Total data of RNA concentrations have been taken at value of A260/280 O.D by being measured using ACTGene Spectrophotometer (ACTGene UVIS-99, NJ and USA). According to these outcomes, the total RNAs of all samples were displayed on the gel, by being adjusted so as to be $0.5 \mu \mathrm{g}$.

\section{cDNA synthesis}

The master mix $2 \mu \mathrm{l}$ for the first step of cDNA synthesis from the RNA obtained was prepared by being completed with ultrapure water so as to be $1 \mu \mathrm{l}$ primer, $1 \mu \mathrm{l}$ dNTP up to a total volume of $14 \mu \mathrm{l}$ and left for $5 \mathrm{~min}$ at $65^{\circ} \mathrm{C}$. Then, the second master mix for the samples taken onto the ice was prepared in quantities as $2 \mu 110 \times$ RTase reaction buffer, $2 \mu \mathrm{l} 0.1 \mathrm{M}$ DTT, $1 \mu \mathrm{l}$ Hyper Script ${ }^{\mathrm{TM}}$ Reverse Transcriptase $(200 \mu \mathrm{l})$ and $1 \mu \mathrm{l} \mathrm{ZymAll}{ }^{\mathrm{TM}}$ RNase Inhibitor, and $6 \mu \mathrm{l}$ hereof was added as per sample. The samples were respectively incubated for $60 \mathrm{~min}$ at $55^{\circ} \mathrm{C}$ and 5 min at $85{ }^{\circ} \mathrm{C}$.

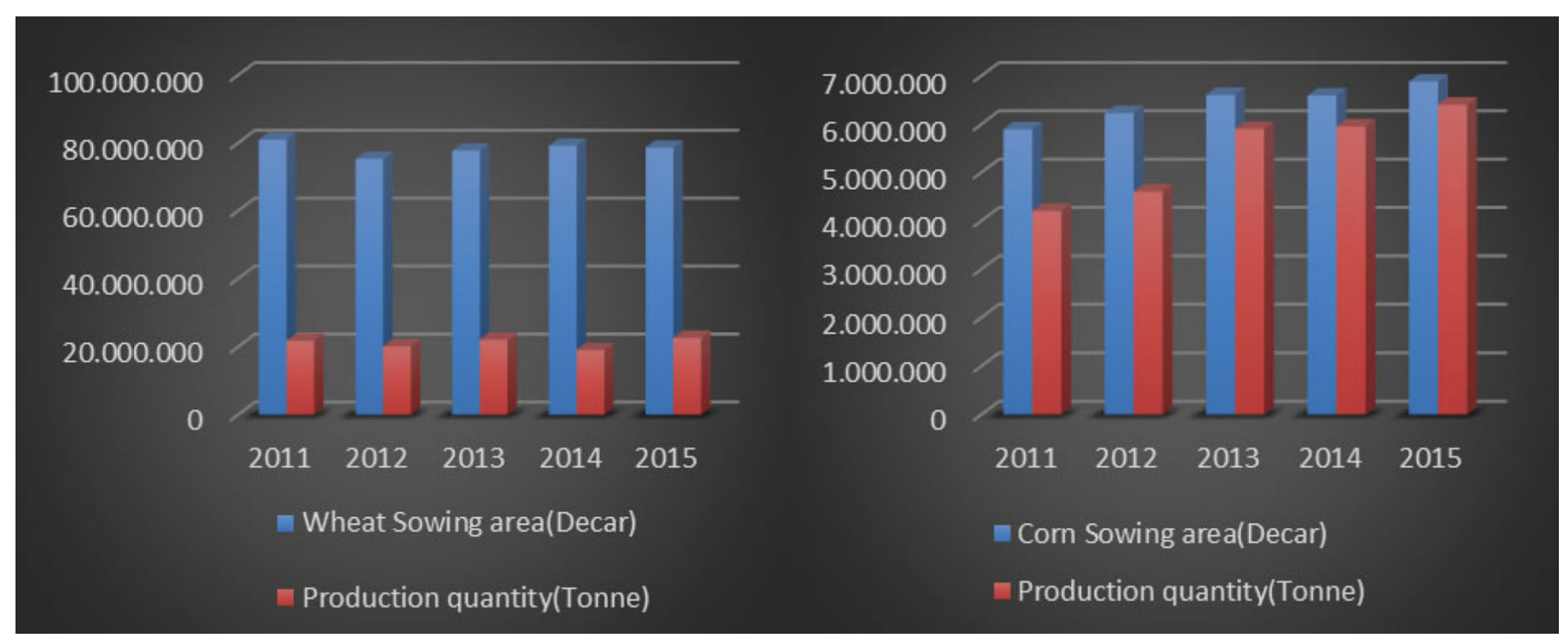

Fig. 1 Plant area and crop yield data for wheat and corn grown in our country 


\section{RT-PCR analysis}

Primers Ta14S1 and Ta14S2 for wheat and ZmGF14-4 and ZmGF14-6 for corn were designed for gene expression of the 14-3-3 protein family. $\beta$-actin has been used as the housekeeping gene. The details pertaining to the primers employed are provided in Table 1. The synthesized cDNAs, primers Ta14S1, Ta14S2, ZmGF14-4, and ZmGF14-6 have been checked by using PCR analysis primer $\beta$-actin (GenBank ID: AB181991.1) has been used as reference. All real-time PCR samples have been executed in 3 repetitions. In RT-PCR analysis, cDNAs diluted at the rate of 1:200 have been used as templates. The RTPCR reaction components and the schedule belonging to reaction temperature cycle are given below. All reactions have been performed on the Bioneer Exicycler $96^{\circledR}$ (Bioneer, South Korea). PCR components and amplification parameters are presented below.

$10 \mu \mathrm{l}$ of $2 \mathrm{X}$ SYBR master mix was prepared at the rates of $0.8 \mu \mathrm{l} \mathrm{F}$ (forward) $(10 \mathrm{pm})$ primer, $0.8 \mu \mathrm{l} \mathrm{R}$ (reverse) $(10 \mathrm{pm})$ primer, $2 \mu \mathrm{l}$ ROX, $4 \mu \mathrm{l}$ cDNA, and $2.4 \mu \mathrm{l}$ ultrapure water and added to the loading wells. By loading $4 \mu \mathrm{l}$ cDNA samples onto them, RT-PCR was carried out at $95{ }^{\circ} \mathrm{C}$ for $10 \mathrm{~min}$ and at $95{ }^{\circ} \mathrm{C}$ for 45 cycles in $15 \mathrm{~s}$ and at $60{ }^{\circ} \mathrm{C}$ for 45 cycles in $1 \mathrm{~min}$.

\section{Data analysis}

The threshold cycle values were used for assessing the gene expression levels obtained from RT-PCR results. Obtained from relative or comparative qualitative quantitation results of threshold cycle value, the $2^{-\Delta \Delta C_{\mathrm{t}}}$ value was used for calculating the gene expression levels [22]. For each of the samples, the mean of $2^{-\Delta \Delta C_{t}}$ values of 10 samples taken from the same point was calculated. Representing the gene expression level, $2^{-\Delta \Delta C_{\mathrm{t}}}$ was computed using the formula below:

$2^{-((a-b)-(c-d))}$, where $a$ is $C_{\mathrm{t}}$ value obtained from the gene used for each of the samples; $b, C_{\mathrm{t}}$ value obtained from the gene used for control group; $c, C_{\mathrm{t}}$ value obtained from $\beta$-actin gene of each of the samples; $d, C_{\mathrm{t}}$ value obtained from $\beta$-actin gene of control group.

\section{Measurement of heavy metal contents in samples by ICP-MS}

Upon application of combustion process as per sample in $8 \mathrm{ml} \mathrm{HNO}_{3}+2 \mathrm{ml} \mathrm{H}_{2} \mathrm{O}_{2}$ at a microwave oven branded ETHOS UP Milestone Connect, $50 \mathrm{ml}$ was diluted. ICPMS analysis was performed by taking $15 \mathrm{ml}$ from the diluted solution. ICP-MS analyses were performed on a device branded Agilent Technologies 7800 (Agilent Technologies SPS 4 Autosamples).

\section{Results}

\section{Gene expression results of wheat samples}

In order to eliminate the margin of error in RT-PCR analysis results, the dimer formation was checked. In order to check the dimer formation of primers, the melting curve analysis was carried out. At the end of melting curve analysis, it was determined that primers formed no dimer.

RT-PCR was employed for Ta14S1 and $\beta$-actin genes of our study and control groups. Threshold cycle $\left(C_{\mathrm{t}}\right)$ values were obtained for using in comparative analysis of samples. $2^{-\Delta \Delta C_{\mathrm{t}}}$, which is a parameter in evaluating the gene expression levels using $C_{\mathrm{t}}$ values, was calculated.

$2^{-\Delta \Delta C_{\mathrm{t}}}$ values of Ta14S1 gene, which we used for determining the gene expression level of wheat, varied between 0.673 and 2.479 . Since generally no change is seen in expression levels of housekeeping genes under the stress conditions, they are used for comparative analyses. The expression level of one of these genes, $\beta$-actin gene,
Table 1 Primers used in RT-PCR

\begin{tabular}{llll}
\hline Primer name & Sequence $5^{\prime} \rightarrow 3^{\prime}$ & TM $\left({ }^{\circ} \mathrm{C}\right)$ & GC\% \\
\hline ZmGF14-4F & GAACCTCTTATCTGTTGCCT & 50 & 45 \\
ZmGF14-4R & GATGACTAGATGCCAGTTCC & 52 & 50 \\
ZmGF14-6F & GCATGCAGAAGGGTTGAGCA & 56 & 57 \\
ZmGF14-6R & TCAGGGCTCATCTAGCTGGTCCTG & 61 & 58 \\
Ta14S-F1 & ACGACTCAAGCGAGGGGCA & 55 & 63 \\
Ta14S-R1 & CGCCTGCTACGCTACAAGGAC & 58 & 62 \\
Ta14S-F2 & GTCAATGACCGTTGCAATGTG & 52 & 48 \\
Ta14S-R2 & GCCACCACCACCACTGTATG & 56 & 60 \\
$\beta$-actin-F & TTTGAAGAGTCGGTGAAGGG & 52 & 50 \\
$\beta$-actin-R & TTTCATACAGCAGGCAAGCA & 50 & 45 \\
\hline
\end{tabular}


was seen to remain low for first 5 samples closest to the heavy metal source. Mean $2^{-\Delta \Delta C_{\mathrm{t}}}$ value of the products grown at closest point to heavy metal source was 0.673 , that of the products grown at 2nd closest point was 0.986 , that of the product grown at 3rd closest point was 0.926 , that of the product grown at the 4th closest point was 0.946 , and the mean $2^{-\Delta \Delta C_{\mathrm{t}}}$ value of the products grown at 5 th closest point to heavy metal source was 0.986 . From the samples at 6th closest point to 20th closest point to heavy metal source, all of the samples were found to have higher gene expression levels than the expression level of $\beta$-actin gene. The comparison of Ta14S1 gene expression with the expression of $\beta$-actin gene is presented in Fig. 2(A).

$2^{-\Delta \Delta C_{\mathrm{t}}}$ values of Ta14S2 gene, which we used for determining the gene expression level of wheat, varied between 0.176 and 2.497. Mean $2^{-\Delta \Delta C_{t}}$ value of the products grown at closest point to heavy metal source was 0.176 , that of the products grown at 2nd closest point was 0.727 , that of the product grown at 3rd closest point was 0.784 , that of the product grown at the 4 th closest point was 0.933 , and the mean $2^{-\Delta \Delta C_{\mathrm{t}}}$ value of the products grown at 5 th closest point to heavy metal source was 0.840 . From the samples at 6th closest point to 20th closest point to heavy metal source, all of the samples were found to have higher gene expression levels than the expression level of $\beta$-actin gene. The comparison of Ta14S2 gene expression with the expression of $\beta$-actin gene is presented in Fig. 2(B).

\section{Gene expression results of corn samples}

$2^{-\Delta \Delta C_{\mathrm{t}}}$ values of ZmGF14-4 gene, which we used for determining the gene expression level of corn, varied between 0.334 and 2.531. Mean $2^{-\Delta \Delta C_{\mathrm{t}}}$ value of the products grown at closest point to heavy metal source was
0.334 , that of the products grown at 2 nd closest point was 0.716 , that of the product grown at $3 \mathrm{rd}$ closest point was 0.582 , that of the product grown at the 4 th closest point was 0.726 , and the mean $2^{-\Delta \Delta C_{\mathrm{t}}}$ value of the products grown at 5 th closest point to heavy metal source was 0.517 . From the samples at 6th closest point to 20th closest point to heavy metal source, all of the samples were found to have higher gene expression levels than the expression level of $\beta$-actin gene. The comparison of ZmGF14-4 gene expression with the expression of $\beta$-actin gene is presented in Fig. 3(A).

$2^{-\Delta \Delta C_{\mathrm{t}}}$ values of ZmGF14-6 gene, which we used for determining the gene expression level of corn, varied between 0.456 and 3.837. Mean $2^{-\Delta \Delta C_{\mathrm{t}}}$ value of the products grown at closest point to heavy metal source was 0.456 , that of the products grown at 2 nd closest point was 0.688 , that of the product grown at 3rd closest point was 0.888 , that of the product grown at the 4 th closest point was 0.920 , and the mean $2^{-\Delta \Delta C_{t}}$ value of the products grown at 5 th closest point to heavy metal source was 0.946 . From the samples at 6th closest point to 20th closest point to heavy metal source, all of the samples were found to have higher gene expression levels than the expression level of $\beta$-actin gene. The comparison of ZmGF14-6 gene expression with the expression of $\beta$-actin gene is presented in Fig. 3(B).

\section{Gene expression level and heavy metal content combination}

$2^{-\Delta \Delta C_{\mathrm{t}}}$ values representing the gene expression levels of wheat and corn samples, the level of expression in comparison with $\beta$-actin gene, and the species of heavy metals found in the plants are presented in Table 2 in comparison with each other. Given these comparisons, the high
(A)

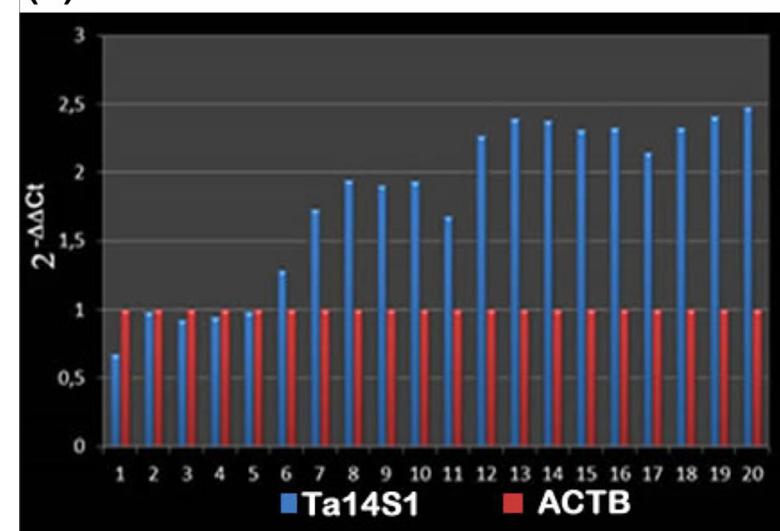

(B)

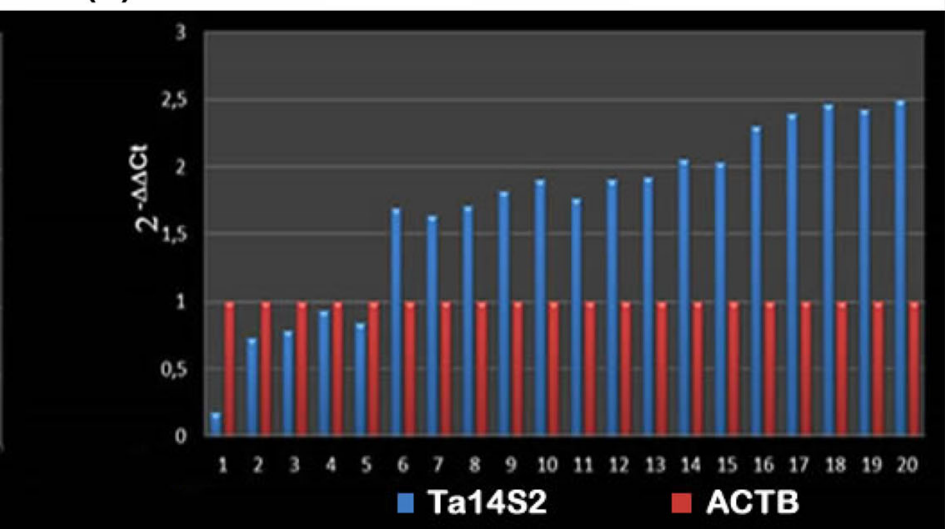

Fig. 2 (A) Diagram of $2^{-\Delta \Delta C_{\mathrm{t}}}$ values obtained for comparing the Ta14S1 gene of wheat with $\beta$-actin gene. (B) Diagram of $2^{-\Delta \Delta C_{\mathrm{t}}}$ values obtained for comparing the Ta14S2 gene of wheat with $\beta$-actin gene 
(A)

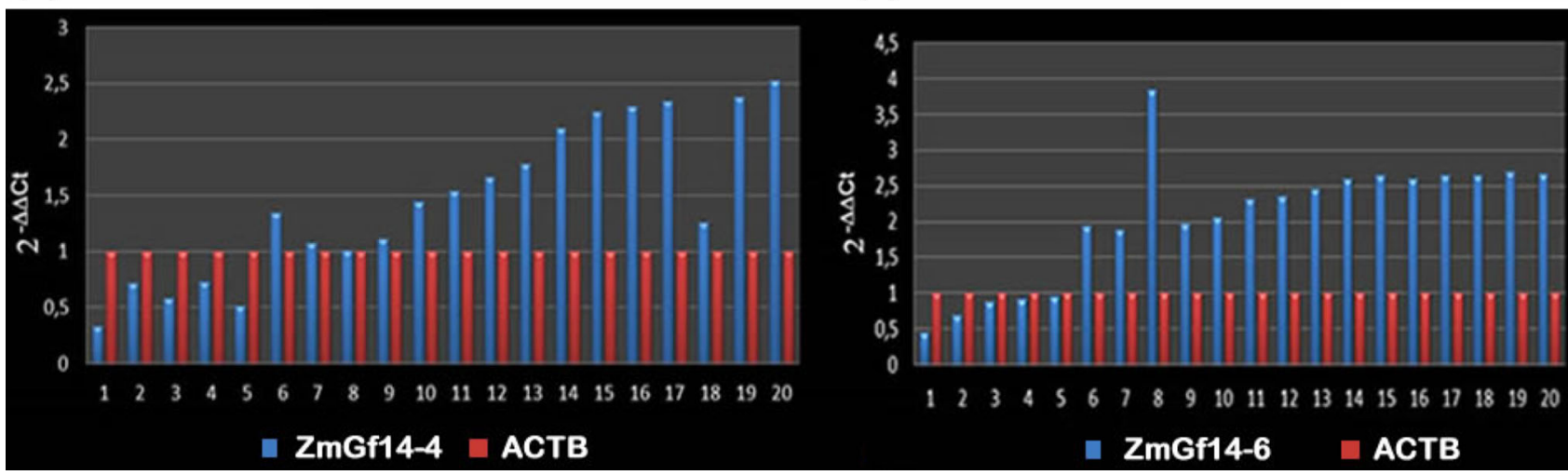

Fig. 3 (A) Diagram of $2^{-\Delta \Delta C_{\mathrm{t}}}$ values obtained for comparing the ZmGF14-4 gene of wheat with $\beta$-actin gene. (B) Diagram of $2^{-\Delta \Delta C_{\mathrm{t}}}$ values obtained for comparing the ZmGF14-6 gene of wheat with $\beta$-actin gene

intensity and diversity of heavy metals are remarkable in first 5 samples. The presence of such diverse and intense heavy metals suppresses the gene expression levels.

\section{Discussion}

Heavy metal contamination is an important environmental problem for living organisms in the world. Particularly, plants are directly exposed to metal-contaminated soil and water [23, 24]. In many studies carried out on the genotoxic effect of lead, it was reported to cause mutations. In addition, for Brassica barley seeds, lead was reported to cause DNA damage and mutations, whereas $\mathrm{Cd}$ was reported to have same effects on Hordeum vulgare and Oryza sativa [8, 25-28].

The gene expression regulation is a very complex process and is thought to be one of the most important mechanisms of heavy metal toxicities. The effects of heavy metals on the changes in gene expression have been reported by using plant and animal models [29-34].

The heavy metal stress is known to influence the plants through the epigenetic changes in chromatin structure such as gene expression, DNA methylation, and posttranslational modifications in histones [35].

In the present study, the gene expression levels of corn and wheat plants grown at various distances from the heavy metal source were determined. The $2^{-\Delta \Delta C_{\mathrm{t}}}$ values obtained from our samples were compared to $2^{-\Delta \Delta C_{\mathrm{t}}}$ values of $\beta$ actin genes, a housekeeping gene, obtained from the same samples. The results we obtained suggest that 14-3-3 protein family, the level of which is increased as a defensive reflex under the stress conditions, is suppressed when exposed to a certain concentration and/or number of heavy metals. High concentration and/or number of heavy metals suppressed the gene expression as a result of epigenetic changes. But, as the distance from heavy metal source increases, then the number and amount of heavy metals contained by the plant were observed to decrease. As a result of this decrease, the gene expression level was found to increase.

Xie et al. [36], in their study, have reported a relationship between 14-3-3 gene expression and $\mathrm{Cd} 2+$, in addition to the connection between the $\mathrm{Cd} 2+$ exposure and 14-3-3 transcriptional regulation. Moreover, 14-3-3s were reported to play a significant role in copper tolerance $[37,38]$. Besides that, the exposure of plants to various levels of heavy metals might not always cause an increase in the expression levels of 14-3-3 proteins. For instance, in their study, Owen et al. [39] reported that the excessive accumulation of copper heavy metal suppressed the 14-3-3 gene expression and led to irrevocable DNA damage.

It has been understood that heavy metal stress causes a difference in gene expression level. The level of stressinduced gene expression, which is caused by heavy metals in the environment surrounding the plant, has been successfully determined by RT-PCR.

\section{Suggestions}

The rapid increase in the world population increases the energy requirement and consumption gradually. For this reason, the use of any available energy source is a necessity. In our country, there are lignite basins, which are very important from this aspect. The utilization of thermal energy plants is an unmissable opportunity for our country. In order to minimize the damage of heavy metals released from the thermal energy plants to the environment, these areas should be used for planting the accumulator plants absorbing the heavy metals into their structures. 
Table 2 Gene expression levels of wheat samples and the determined heavy metals

\begin{tabular}{|c|c|c|c|c|c|c|c|c|c|c|c|c|}
\hline \multicolumn{13}{|l|}{ Wheat } \\
\hline \multirow[t]{3}{*}{ Sample numbers } & \multicolumn{4}{|c|}{ Gene expression } & \multirow{2}{*}{\multicolumn{8}{|c|}{ Heavy metals in construction }} \\
\hline & \multicolumn{2}{|l|}{ Ta14S1 } & \multicolumn{2}{|l|}{ Ta14S2 } & & & & & & & & \\
\hline & $2^{-\Delta \Delta C_{\mathrm{t}}}$ value & Exp. level & $2^{-\Delta \Delta C_{\mathrm{t}}}$ value & Exp. level & $\mathrm{Cr}$ & $\mathrm{Mn}$ & $\mathrm{Fe}$ & $\mathrm{Ni}$ & $\mathrm{Cu}$ & $\mathrm{Zn}$ & $\mathrm{Cd}$ & $\mathrm{Pb}$ \\
\hline 1 & 0.673 & Low & 0.176 & Low & + & + & + & + & + & + & + & + \\
\hline 2 & 0.986 & Low & 0.726 & Low & + & - & + & + & + & + & + & + \\
\hline 3 & 0.926 & Low & 0.784 & Low & + & - & + & + & + & + & + & + \\
\hline 4 & 0.946 & Low & 0.933 & Low & + & - & + & + & + & + & - & + \\
\hline 5 & 0.986 & Low & 0.840 & Low & + & - & - & + & + & + & - & + \\
\hline 6 & 1.729 & High & 1.635 & High & - & - & - & + & + & + & - & + \\
\hline 7 & 1.283 & High & 1.693 & High & + & - & - & + & + & + & - & + \\
\hline 8 & 1.945 & High & 1.705 & High & - & - & - & + & + & + & - & + \\
\hline 9 & 1.905 & High & 1.815 & High & - & - & - & + & + & + & - & + \\
\hline 10 & 1.931 & High & 1.905 & High & - & - & - & + & + & + & - & + \\
\hline 11 & 1.681 & High & 1.765 & High & - & - & - & + & + & + & - & - \\
\hline 12 & 2.265 & High & 1.905 & High & - & - & - & + & + & + & - & - \\
\hline 13 & 2.394 & High & 1.918 & High & - & - & - & - & - & - & - & - \\
\hline 14 & 2.378 & High & 2.056 & High & - & - & - & - & - & - & - & - \\
\hline 15 & 2.313 & High & 2.027 & High & - & - & - & - & - & - & - & - \\
\hline 16 & 2.329 & High & 2.297 & High & - & - & - & - & - & - & - & - \\
\hline 17 & 2.143 & High & 2.394 & High & - & - & - & - & - & - & - & - \\
\hline 18 & 2.329 & High & 2.462 & High & - & - & - & - & - & - & - & - \\
\hline 19 & 2.411 & High & 2.428 & High & - & - & - & - & - & - & - & - \\
\hline 20 & 2.479 & High & 2.496 & High & - & - & - & - & - & - & - & - \\
\hline \multicolumn{13}{|l|}{ Corn } \\
\hline \multirow[t]{3}{*}{ Sample numbers } & \multicolumn{4}{|c|}{ Gene expression } & \multirow{2}{*}{\multicolumn{8}{|c|}{ Heavy metals in construction }} \\
\hline & \multicolumn{2}{|l|}{ ZmGF14-4 } & \multicolumn{2}{|l|}{ ZmGF14-6 } & & & & & & & & \\
\hline & $2^{-\Delta \Delta C_{\mathrm{t}}}$ value & Exp. level & $2^{-\Delta \Delta C_{\mathrm{t}}}$ value & Exp. level & $\mathrm{Cr}$ & $\mathrm{Mn}$ & $\mathrm{Fe}$ & $\mathrm{Ni}$ & $\mathrm{Cu}$ & $\mathrm{Zn}$ & $\mathrm{Cd}$ & $\mathrm{Pb}$ \\
\hline 1 & 0.334 & Low & 0.456 & Low & + & + & + & + & + & + & + & + \\
\hline 2 & 0.716 & Low & 0.687 & Low & + & + & + & + & + & + & + & + \\
\hline 3 & 0.582 & Low & 0.888 & Low & + & + & - & + & + & + & + & + \\
\hline 4 & 0.726 & Low & 0.920 & Low & + & - & - & + & + & + & + & + \\
\hline 5 & 0.517 & Low & 0.946 & Low & - & - & - & + & + & + & - & + \\
\hline 6 & 1.347 & High & 1.945 & High & - & - & - & + & + & + & + & + \\
\hline 7 & 1.071 & High & 1.892 & High & - & - & - & + & + & + & - & + \\
\hline 8 & 1.006 & High & 3.837 & High & - & - & - & + & + & + & - & + \\
\hline 9 & 1.109 & High & 1.972 & High & - & - & - & + & + & + & - & + \\
\hline 10 & 1.443 & High & 2.070 & High & - & - & - & + & + & + & - & - \\
\hline 11 & 1.536 & High & 2.329 & High & - & - & - & + & + & + & - & - \\
\hline 12 & 1.670 & High & 2.361 & High & - & - & - & - & + & - & - & - \\
\hline 13 & 1.777 & High & 1.462 & High & - & - & - & - & - & - & - & - \\
\hline 14 & 2.099 & High & 2.602 & High & - & - & - & - & - & - & - & - \\
\hline 15 & 2.25 & High & 2.657 & High & - & - & - & - & - & - & - & - \\
\hline 16 & 2.297 & High & 2.602 & High & - & - & - & - & - & - & - & - \\
\hline 17 & 2.345 & High & 2.657 & High & - & - & - & - & - & - & - & - \\
\hline 18 & 1.257 & High & 2.657 & High & - & - & - & - & - & - & - & - \\
\hline
\end{tabular}


Table 2 continued

\begin{tabular}{|c|c|c|c|c|c|c|c|c|c|c|c|c|}
\hline \multicolumn{13}{|l|}{ Corn } \\
\hline \multirow[t]{3}{*}{ Sample numbers } & \multicolumn{4}{|c|}{ Gene expression } & \multicolumn{8}{|c|}{ Heavy metals in construction } \\
\hline & \multicolumn{2}{|l|}{ ZmGF14-4 } & \multicolumn{2}{|l|}{ ZmGF14-6 } & & & & & & & & \\
\hline & $2^{-\Delta \Delta C_{\mathrm{t}}}$ value & Exp. level & $2^{-\Delta \Delta C_{\mathrm{t}}}$ value & Exp. level & $\mathrm{Cr}$ & $\mathrm{Mn}$ & $\mathrm{Fe}$ & $\mathrm{Ni}$ & $\mathrm{Cu}$ & $\mathrm{Zn}$ & $\mathrm{Cd}$ & $\mathrm{Pb}$ \\
\hline 19 & 2.378 & High & 2.694 & High & - & - & - & - & - & - & - & - \\
\hline 20 & 2.531 & High & 2.675 & High & - & - & - & - & - & - & - & - \\
\hline
\end{tabular}

The studies on the genotoxic effects of heavy metals are based generally on the implementation of heavy metals individually and at various doses. But, given the factors causing the release of heavy metals to the nature, it can be seen that multiple heavy metals are released into the nature at the same time. From this aspect, by accurately analyzing the distribution combinations, it would be better to use these heavy metals together in studies in order to obtain more objective results.

Among the living creatures, there is a constant food chain. From this aspect, we believe that it would be better to pay attention that the nutrients to be grown will be planted at a distance from toxic sources that lead to genotoxic effects and epigenetic changes.

It has also been noted in our literature that heavy metals have a genotoxic effect on plants. Considering this situation, we believe that it would be more appropriate to determine the types of grains with high heavy metal tolerance around the facilities which cause heavy metal pollution and to plant these species.

Acknowledgments Thank you Professor Dr. Güleray AĞAR. This study was financed under the Project Number 445 by Erzincan University BAP coordinator. This article is based on a doctoral dissertation titled Genetic and Epigenetic Changes in Heavy Metals Found in Cubes Driven from Thermal Plants.

\section{References}

1. Grigoratos T, Martini G (2014) Brake wear particle emissions: a review. Environ Sci Pollut Res 22(4):2491-2504

2. Sawidis T, Breuste J, Mitrovic M, Pavlovic P, Tsigaridas K (2011) Trees as bioindicator of heavy metal pollution in three European cities. Environ Pollut 159(12):3560-3570. https://doi. org/10.1016/j.enviromentalpollution.2011.08.008

3. Sharma VM, Tomar RS, Dempsey AE, Reese JC (2007) Histone deacetylases RPD3 and HOS2 regulate the transcriptional activation of DNA damage-inducible genes. Mol Cell Biol 27(8):3199-3210

4. Qishlaqi A, Moore F, Forghani G (2008) Impact of untreated wastewater irrigation on soils and crops in Shiraz suburban area, SW Iran. Environ Monit Assess 141:257-273
5. Vousta D, Gramanis A, Samara C (1996) Trace elements in vegetables grown in an industrial area in relation to soil and air particulate matter. Environ Pollut 94:325-335

6. Zhang L, Zhang L, Liu N, Ma X, Jiang L (2013) The transcriptional control machinery as well as the cell wall integrity and its regulation are involved in the detoxification of the organic solvent dimethyl sulfoxide in Saccharomyces cerevisiae. FEMS Yeast Res 13(2):200-218

7. Ariza ME, Williams MV (1999) Lead and mercury mutagenesis: type of mutation dependent upon metal concentration. J Biochem Mol Toxicol 13(2):107-112

8. Cenkci S, Yildiz M, Ciǧerci IH, Konuk M, Bozdağ A (2009) Toxic chemicals-induced genotoxicity detected by random amplified polymorphic DNA (RAPD) in bean (Phaseolus vulgaris L.) seedlings. Chemosphere 76:900-906. https://doi.org/10. 1016/j.chemosphere.2009.05.001

9. Liu S, Dixon K (1996) Induction of mutagenic DNA damage by chromium (VI) and glutathione. Environ Mol Mutagen 28(2):71-79

10. Mokdad AH, Marks JS, Stroup DF (2004) Actual causes of death in the United States, 2000. JAMA 291(10):1238-1245. https:// doi.org/10.1001/jama.291.10.1238

11. Zhang L, Zhou W, Velculescu VE, Kern SE, Hruban RH, Hamilton SR, Vogelstein B, Kinzler KW (1997) Gene expression profiles in normal and cancer cells. Science 276(5316): 1268-1272

12. Xu H, Fairman JW, Wijerathna SR, Kreischer NR, LaMacchia J, Helmbrecht E, Cooperman BS, Dealwis C (2008) The structural basis for peptidomimetic inhibition of eukaryotic ribonucleotide reductase: a conformationally flexible pharmacophore. J Med Chem 51(15):4653-4659

13. Bal W, Kasprzak KS (2002) Induction of oxidative DNA damage by carcinogenic metals. Toxicol Lett 127(1-3):55-62

14. Costa MR, Wilson ET, Wieschaus E (1994) A putative cell signal encoded by the folded gastrulation gene coordinates cell shape changes during Drosophila gastrulation. Cell 76(6):1075-1089 (export to RIS)

15. Koppen G, Verschaeve L (1996) The alkaline comet test on plant cells: a new genotoxicity test for DNA strand breaks in Vicia faba root cells. Mutat Res 360(3):193-200

16. Kovalchuk O, Titov V, Hohn B, Kovalchuk I (2001) A sensitive transgenic plant system to detect toxic inorganic compounds in the environment. Nat Biotechnol 19:568-572

17. Mediouni C, Benzarti O, Tray B, Ghorbel MH, Jemal F (2006) Cadmium and copper toxicity for tomato seedlings. Agron Sustain Dev 26:227-232. https://doi.org/10.1051/agro:2006008

18. Ralph J, Hatfield RD, Grabber JH, Jung HG, Quideau S, Helm RF (1998b) Cell wall cross-linking in grasses by ferulates and 59 diferulates. In: Lewis NG, Sarkanen S (ed) Lignin and lignan 
biosynthesis, vol 697, American Chemical Society Symposium Series. American Chemical Society, Washington, pp 209-236

19. Rodenhiser D, Mann M (2006) Epigenetics and human disease: translating basic biology into clinical applications. CMAJ 174(3):341-348

20. Dawson MA, Kouzarides T (2012) Cancer epigenetics: from mechanism to therapy. Cell 150(1):12-27. https://doi.org/10. 1016/j.cell.2012.06.013

21. Turkish Statistical Institute (2016). http://www.turkstat.gov.tr/ UstMenu.do?metod=temelist

22. Rao X, Xuelin H, Zhicheng Z, Xin L (2013) An improvement of the $2^{-\Delta \Delta C t}$ method for quantitative real-time polymerase chain reaction data analysis. Biostat Bioinforma Biomath 3(3):71-85

23. Aydin SS, Gokce E, Buyuk I, Aras S (2012) Characterization of stress induced by copper and zinc on cucumber (Cucumis sativus L.) seedlings by means of molecular and population parameters. Mutat Res 746:49-55

24. Erturk FA, Nardemir G, Ay H, Arslan E, Agar G (2013) Determination of genotoxic effects of boron and zinc on Zea mays $\mathrm{L}$. by using protein and RAPD analyses. Toxicol Ind Health. https:// doi.org/10.1177/0748233713485888

25. Aksoy D, Aras S (2010) Evaluation of copper-induced stress on eggplant (Solanum melongena L.) seedlings at the molecular and population levels by use of various biomarkers. Mutat Res. https://doi.org/10.1016/j.mrgentox.2010.10.003

26. Conte C, Mutti I, Puglisi P, Marmiroli N (1998) DNA fingerprinting analysis by a PCR based method for monitoring the genotoxic effects of heavy metals pollution. Chemosphere 37(14-15):2739-2749. https://doi.org/10.1016/S0045-6535(98)0 0317-8

27. Liu L, Wang YX, Zhou J, Long F, Sun HW, Liu Y, Chen YZ, Jiang CL (2005) Rapid non-genomic inhibitory effects of glucocorticoids on human neutrophil degranulation. Inflamm Res 54(1):37-41

28. Liu L, Bailey SM, Okuka M, Muñoz P, Li C, Zhou L, Wu C, Czerwiec E, Sandler L, Seyfang A, Blasco MA, Keefe DL (2007) Telomere lengthening early in development. Nat Cell Biol 9(12):1436-1441

29. Bartosiewicz M, Penn S, Buckpitt A (2001) Applications of gene arrays in environmental toxicology: fingerprints of gene regulation associated with cadmium chloride, benzo(a)pyrene, and trichloroethylene. Environ Health Perspect 109:71-74

30. Chen F, Li Q, Sun L, He Z (2006) The rice 14-3-3 gene family and its involvement in responses to biotic and abiotic stress. DNA Res 13:53-63

31. Li Z, Wang L, Hays TS, Cai Y (2008) Dynein-mediated apical localization of crumbs transcripts is required for Crumbs activity in epithelial polarity. J Cell Biol 180(1):31-38

32. Miller RL, Tegen I, Perlwitz JP (2004) Surface radiative forcing by soil dust aerosols and the hydrologic cycle. J Geophys Res 109:D04203. https://doi.org/10.1029/2003JD004085

33. Nair S, Traini M, Dawes IW, Perrone GG (2014) Genome-wide analysis of Saccharomyces cerevisiae identifies cellular processes affecting intracellular aggregation of Alzheimer's amyloid- $\beta 42$ : importance of lipid homeostasis. Mol Biol Cell 25(15):2235-2249

34. Zhou W, Ryan JJ, Zhou H (2004) Global analyses of sumoylated proteins in Saccharomyces cerevisiae. Induction of protein sumoylation by cellular stresses. J Biol Chem 279(31):32262-32268

35. Grativol C, Hemerly AS, Ferreira PCG (2012) Genetic and epigenetic regulation of stress responses in natural plant populations. Biochim Biophys Acta 1819:176-185

36. Xie C, Liujie H, Yongzhu Y, Dunxiu L, Xingyong Y (2017) Accumulation and tolerance to cadmium heavy metal ions and induction of 14-3-3 gene expression in response to cadmium exposure in Coprinus atramentarius. Microbiol Res 196:1-6

37. Chen J, Li X, Wang D, Li L, Zhou H, Liu Z, Wu J, Wang P, Jiang X, Fabrice MR, Zhang S, Wu J (2015) Identification and testing of reference genes for gene expression analysis in pollen of Pyrus bretschneideri. Sci Hortic 190:43-56

38. Hall JL, Williams LE (2003) Transition metal transporters in plants. J Exp Bot 54(393):2601-2613

39. Owen JR, Morris CA, Nicolaus B, Harwood JL, Kille P (2012) Induction of expression of a 14-3-3 gene in response to copper exposure in the marine alga, Fucus vesiculosus. Ecotoxicology 21(1):124-138 